\title{
Seed storage proteins of faba bean (Vicia faba $L)$ : current status and prospects for genetic improvement
}

Article

Accepted Version

Warsame, A. O., O'Sullivan, D. M. and Tosi, P. (2018) Seed storage proteins of faba bean (Vicia faba $L$ ): current status and prospects for genetic improvement. Journal of Agricultural and Food Chemistry, 66 (48). pp. 12617-12626. ISSN 0021-8561 doi: https://doi.org/10.1021/acs.jafc.8b04992 Available at https://centaur.reading.ac.uk/80856/

It is advisable to refer to the publisher's version if you intend to cite from the work. See Guidance on citing.

To link to this article DOI: http://dx.doi.org/10.1021/acs.jafc.8b04992

Publisher: American Chemical Society

All outputs in CentAUR are protected by Intellectual Property Rights law, including copyright law. Copyright and IPR is retained by the creators or other copyright holders. Terms and conditions for use of this material are defined in the End User Agreement.

www.reading.ac.uk/centaur 
Central Archive at the University of Reading

Reading's research outputs online 
Page 1 of 35

\section{Seed storage proteins of faba bean (Vicia faba): current status}

\section{2 and prospects for genetic improvement}

3 Ahmed O. Warsame*, Donal M. O’Sullivan and Paola Tosi

4 School of Agriculture, Policy and Development, University of Reading, Reading, RG6 6AR,

5 United Kingdom

6 Correspondence: Ahmed Omar Warsame

7 Phone: $+44(0) 1183785473$

$8 \quad$ Email: $\underline{\text { A.OmarWarsame@pgr.reading.ac.uk }}$ 
Page 2 of 35

26 ABSTRACT

27 Faba bean (Vicia faba, L.) is one of the foremost candidate crops for simultaneously 28 increasing both sustainability and global supply of plant protein. Its seeds contain about $27 \%$ 29 proteins of which more than $80 \%$-consist of globulin storage proteins (vicilin and legumin).

30 For optimum utilization for human and animal nutrition, both protein content and quality 31 have to be improved. Though initial investigations on the hereditability of these traits

32 indicated possibility for genetic improvement, little has been achieved so far partly due to 33 lack of genetic information coupled with the complex relationship between protein content 34 and grain yield. This review reports on the current knowledge on faba bean seed storage 35 proteins; their structure, composition and genetic control and highlights key areas for further improvement of the content and composition of faba bean seed storage proteins on the basis of recent advances in faba bean genome knowledge and genetic tools.

38

39

2

3

Key words: Vicia faba; sustainability; storage proteins; legumin and vicilin; genetic improvement

4

45


Page 3 of $\mathbf{3 5}$

\section{INTRODUCTION}

\section{Faba bean production and utilization}

53 Nearly $60 \%$ of the global protein supply for human nutrition is sourced from plants ${ }^{1-2}$ and 54 about one third of this originates from grain legumes of the Fabaceae family ${ }^{3}$. Besides their 55 nutritional significance, legume crops ability to fix atmospheric nitrogen via rhizobial 56 symbiosis makes them invaluable components of sustainable crop production systems ${ }^{4}$. Faba 57 bean (Vicia faba, hereafter Vf), also known as fava bean, broad bean, horse bean or field bean $585^{5}$ is one of the world's oldest legume crops, its cultivation dating back to the $10^{\text {th }}$ millennium $59 \mathrm{BC}^{6-7}$. From its origin in the Near East, $V f$ spread to the rest of the globe ${ }^{7}$ and is currently 60 cultivated in nearly 70 countries over the world (Figure 1A), occupying about 2.2 million ha 61 that produce nearly 4 million tons annually ${ }^{8}$. China is the leading $V f$ producer with $36 \%$ of 62 the global output, followed by Ethiopia (20\%), Australia (10\%) and United Kingdom (6\%)

63 (Figure 1B). The wide geographical distribution of $V f$ implies not only a great adaptation to 64 diverse environmental conditions, but also suitability for diverse end uses and trade across 65 continents.

66 Seeds of $V f$ contain on average about $27 \%$ protein ${ }^{9-11}$ which provides affordable nutrition for 67 millions of people around the world, hence its denomination as "the poor man's meat". While $68 V f$ has been traditionally utilized as dry grain for human consumption in developing countries, there is growing interest from food industries in developed countries to exploit its 70 protein for the production of protein-rich vegan/vegetarian snacks, ${ }^{12}$, the fortification of cereal-based food products such as bread and pasta without significantly affecting their

72 structural and sensory quality ${ }^{13-14}$, or even the production of wholly $V f$-based bread and 73 pasta products ${ }^{15}$. Vf also represents as significant resource for agro-ecosystem sustainability 74 and provision of feed for the growing global livestock inventory. Overall, the global production area for $V f$ has been increasing in the last two decades (Figure S1A) and a recent 
Page 4 of $\mathbf{3 5}$

meta-analysis of yield data from 39 legume species indicated that, in the right environment, $V f$ can be the highest yielding grain legume ${ }^{16} . V f$ also has a high capacity for biological nitrogen fixation, to the extent that the amount of $\mathrm{N}$ fixed by $V f$ alone was estimated to be comparable to that of soybean and pea combined ${ }^{17}$. For further details on the role of $V f$ on sustainable cropping systems, readers are referred to Jensen, et al. ${ }^{18}$, Köpke and Nemecek ${ }^{19}$.On the other hand, $V f$ is yet to be fully exploited as a feedstock for animal production due to presence of some anti-nutrients which limit its optimal inclusion ratio ${ }^{20-22}$. Removal of these anti-nutrients through the development of new low anti-nutrient cultivars or using simple processing techniques like fermentation ${ }^{13-14}$ would make this crop a valuable protein resource for the animal production industry.

\section{Faba bean as a sustainable global protein resource}

One of the greatest challenges in the $21^{\text {st }}$ century is feeding the growing world population which it has been estimated may necessitate a $70 \%$ increase in food production by $2050{ }^{4}$. More than $30 \%$ of this increase has to be made via the production of protein-rich foods ${ }^{1}$ to meet the expected rise in demands due to population growth, increased urbanization and improved incomes in many parts of the world ${ }^{1,23-25}$. Protein is a critical nutrient required in large quantity by humans ( $\sim 50 \mathrm{~g}$ protein per adult per day) to maintain normal body function ${ }^{26}$ However,t about one-third of the world population, mainly in Asia, Africa and Latin America, suffers from inadequate intake of proteins, vitamins and minerals ${ }^{27}$. On the other hand, in higher income countries, where daily animal-based protein intake is already high ${ }^{1}$, ${ }^{25}$, continued provision of nutritious feeds for the intensive animal production industry will pose a major challenge in the future. In particular, the livestock production sector in soybean non-producing countries will be burdened by the high price of imported soybean and soybean meal. For instance, EU countries have huge deficit in protein-rich feeds with nearly $70 \%$ being imported ${ }^{28} . V f$ is well-adapted to European climates, as testified by the high yields 
Page $\mathbf{5}$ of $\mathbf{3 5}$

101

102

103

104

105

recorded in this continent for this legume (Figure S1B), and it therefore has the potential to contribute to bridging the gap in animal feed self-sufficiency as part of the EU's policies to increase protein production from locally grown crops ${ }^{28}$. $V f$ is also a candidate crop to meet the protein demands of an emerging consumer category, particularly in developed economies, who are opting for animal meat free life style. For example, Statista ${ }^{29}$ reported that $13 \%$ of European citizens would consider avoiding red meat while nearly $50 \%$ of the respondents in another study were willing to replace meat with other sources of proteins ${ }^{30}$.

Considering the projected impact of climate change on global crop production, meeting the nutritional requirements of the current and future generations would necessitate increased exploitation of the global genetic and natural resources for protein production systems based increasingly on biological nitrogen fixation. In this context, the fact that $V f$ is a high-yielding protein-rich crop with superior $\mathrm{N}$ fixation capability makes it a candidate crop for supporting increased protein production while maintaining sustainability of crop production systems.

\section{Nutritional constraints to $\boldsymbol{V} \boldsymbol{f}$ utilization}

The main determinants of $V f$ utilization for human food and animal feed include: (i) protein concentration, (ii) protein quality, defined mainly by the content of sulfur-containing amino acids (S-AA) cysteine and methionine, and (iii) concentration of antinutrients in the seeds ${ }^{5}$. Protein concentration of $V f$, although it can vary greatly between different genotypes (19-39 $\%)^{31-33}$, is one of the highest among legumes. However, commercial varieties on the UK market contain about $27 \%$ protein on average, which is still far less than the protein density of soya meal, and so, further improvements in protein content is required in order for faba bean to displace imported soya in animal feed. The proportion of S-AA in the protein is another crucial quality criterion, particularly in animal feeding. However, like most plant proteins, $V f$ is poor in certain essential amino acids, namely methionine, cysteine and tryptophan ${ }^{5}$. Though relatively narrow, the genetic variation for the S-AA reported in $V f$ 
Page 6 of 35

126 indicates possibility of improving its nutritional quality. So far, the major breeding objectives

127 for $V f$, have been the reduction or removal of vicine and convicine $(\mathrm{V}-\mathrm{C})$ and tannins: V-C

128 causes favism in humans and have deleterious effects on animals ${ }^{34-35}$ while tannins lower

129 protein digestibility ${ }^{10}$. Although these compounds can be removed by processing techniques

$130 \quad 36-37$, the most effective approach is probably removing them by breeding. This is now

131 feasible with the availability of molecular markers closely linked to the V-C locus ${ }^{38}$ and zero

132 tannin gene (zt-1) ${ }^{39}$. Furthermore, the reduction of less significant antinutrients such as

133 trypsin inhibitors, lectins and phytates would improve the nutritional value of $V f$ based feed

134 products.

135

136

137

138

139

140

141

142

143

144

145

146

147

148

149

150

Understanding the genetic basis of the above limiting factors is a prerequisite for the development of new cultivars with desirable agronomic and nutritional attributes. Unfortunately, while scientific interest in Vf was high during 1970's and 1980's, when it became the model species for studying plant cytogenetics and stomatal regulation, $V f$ can now be considered an orphan crop ${ }^{40}$. For instance, less than $5 \%$ of the publications on legumes in the years 2004-2013 referred to $V f^{9}$. This is further reflected by the scarcity of information on the genetics of many important traits including protein content and quality, for which not a single QTL (Quantitative Trait Loci) has been reported, compared to 160 QTLs from 35 independent studies on soybean protein content ${ }^{41}$. In this context, in order for future work to proceed on a sound basis, we felt there was a need to marry the earlier biochemical literature, where the main species of storage protein were separated and classified, with the later genomic literature, which is replete with unannotated storage protein sequences and implicit map locations. The remainder of this review is devoted to a synthesis of the literature on $V f$ seed storage proteins, covering sequence, structure, composition and genetic basis for their synthesis and accumulation as well as taking a forward look at how this synthesis might be exploited in future research aiming to increase protein content and/or quality. 
Page 7 of 35

\section{SEED STORAGE PROTEINS OF FABA BEAN}

152 The major storage proteins of legumes are mainly enzymatically inactive proteins deposited

153 in seed cotyledons which provide nutrients needed for seed germination and seedling growth

154 and development ${ }^{42-43}$. Certain seed proteins in legumes including albumins and trypsin 155 inhibitors, however, have been identified as antinutritional or allergenic agents and therefore 156 are targeted for removal in breeding programs ${ }^{44}$. Seed storage proteins are classified 157 according to the system developed by TB Osborne which is based on their solubility in 158 different solvents ${ }^{43}$. Albumins and globulins are the major storage proteins of legumes and subunits $(\mathrm{Mr}=\sim 38-40$ and $23 \mathrm{kDa})$ (Table 1)

Legumin and vicilin share notable sequence and structural homology and are believed to

174 originate from a common ancestral gene ${ }^{46}$. Mature legumin is hexameric with a mass of 175 about $330 \mathrm{kDa}^{45}$ and is composed of two trimeric subunits (legumin A and B) while vicilin is 
Page $\mathbf{8}$ of $\mathbf{3 5}$

176 a trimeric protein formed by the assembly of three monomers (Figure 2). In contrast to

177 legumin, vicilin lacks cysteine and is usually glycosylated in its C-terminus ${ }^{46}$. These 178 structural variations may result in differences in the physiochemical properties of seed 179 storage proteins which in turn determine their nutritional value and utilization. For instance, 180 legumin and vicilin differ in their thermal properties ${ }^{47-48}$, affinity to bind flavor compounds 181 under varying $\mathrm{pH}$ conditions ${ }^{49}$ and emulsifying ability ${ }^{48}$. Therefore, from a breeding point of 182 view, legumin/vicilin ratio could be manipulated to meet certain end-user requirements for 183 protein functionality.

\section{Structure and composition of $\boldsymbol{V} \boldsymbol{f}$ globulins}

185 Legumin constitutes more than $50 \%$ of $V f$ globulins ${ }^{45}$. It is a hexameric protein with two major subunits - the $\alpha$ and $\beta$ chains - which are connected by disulphide bonds. Under reducing conditions, these subunits form two bands of molecular weights of about 40 and 24 $\mathrm{kDa}$, respectively (Figure 3). These subunits are also referred to as acidic and basic subunits or simply legumin A and B. Polypeptides of both legumins are highly homologous but notably distinguishable by the presence of more methionine residues in the peptide sequences of legumin A subunits ${ }^{50}$. Vf legumin A subunits appear to be more variable and show polymorphic bands between genotypes ${ }^{51}$ as is also the case with Medicago legumin $\mathrm{A}^{52}$. On the other hand, vicilin-type proteins of $V f$ are trimeric ${ }^{45}$ consisting predominantly of subunits of $\sim 50 \mathrm{kDa}$ while bands of $\sim 66 \mathrm{kDa}$ are referred as convicilin ${ }^{42,51}$. The classification of $7 \mathrm{~S}$ proteins into vicilin and convicilin was first coined in pea and has been accepted in many legumes including $V f$ (Table 1). Nonetheless, further investigation into their possible structural and functional differences have concluded that convicilin may be regarded as subunit of vicilin ${ }^{53}$. Such a denotation exists in soybean whereby subunits of $7 \mathrm{~S}$ protein are categorized into $\alpha^{\prime}(\sim 76 \mathrm{kDa}), \alpha(\sim 72 \mathrm{kDa})$, and $\beta(\sim 53) \mathrm{kDa}{ }^{54-55}$. 
Page 9 of 35

200 Regarding amino acid composition, nearly $50 \%$ of $V f$ seed protein is accounted for by just a

201 few non-essential amino acids such as glutamic acid, aspartic acid, arginine and leucine while

202 it is low in essential amino acids particularly S-AA (Figure 4). The concentration of S-AA is

203 a critical determinant of the nutritional value of plant proteins destined for human

204 consumption and animal feeding. In humans, dependence on poor quality proteins can result

205 in reduced immunity and underdeveloped mental and physical capacity among young

206 children ${ }^{56}$. Also, animal feeds deficient in critical amino acids can cost farmers in form of

207 animal feed supplements of industrially synthesized S-AA ${ }^{55}$.

208 The concentration of S-AA is strongly related to the relative proportions of S-AA rich 209 proteins in the seeds. In $V f$ and other legumes, it is well accepted that legumins contain 210 relatively higher S-AA compared to vicilin 42, 44, 57-58. This is further confirmed by 211 comparative analysis of coding sequences of vicilin and legumin subunits across legume 212 species which clearly show that legumin subunits contain more residues of cysteine and 213 methionine (Figure 4). This observation leads to the hypothesis that increasing the proportion 214 of legumin subunits relative to vicilin would improve nutritional content of plant proteins. 215 However, considering that vicilin is accumulated in legume seeds earlier than legumin ${ }^{59-61}$, 216 their ratios could be easily offset by the prevailing environmental conditions, e.g. soil 217 nutritional status and onset of biotic and abiotic stresses during the plant growth, and in 218 particular, during grain filling. In contrast to globulins, minor legume seed proteins such as 219 elongation factor Tu, citrate synthase, albumin 2 (PA2), defensins 1 and 2 and Bowman-Birk 220 inhibitors (BBI) contain higher S-AA ${ }^{42,62}$. According to Krishnan, et al. ${ }^{63}$, under higher N 221 availability through fertilizer application or symbiotic fixation, S-AA containing proteins like 222 Bowman-Birk protease inhibitor (BBI) were decreased in favour of $\beta$-subunits of $\beta$ 223 conglycinins of soybeans. Similarly, ectopic overexpression of VfAAPl gene on P. sativum 224 and $V$. narbonensis resulted in 30\% increase in the globulin fraction but no significant effect 
Page 10 of $\mathbf{3 5}$

225 on albumin, a S-AA rich protein ${ }^{64}$. Hence, it would appear that the negative correlation

226 between high protein and S-AA content in $V f^{11,32,65}$ may be the result of preferential

227 accumulation of low nutritional quality protein fractions in higher protein lines.

\section{Genetic control of globulins}

229 Globulins are by far the most abundant seed proteins in legumes and, subsequently, their 230 genetic control has been well investigated. In $V f$, legumin subunit is encoded by relatively 231 few genes which are classified as legumin A and B genes. A single legumin A gene has been 232 located on the telomeric region of chromosome $\mathrm{V}$ of $V f^{66}$. It is not clear, however, whether 233 the legumin A2 gene ( $\operatorname{Leg} A 2)$ reported in pea ${ }^{67}$ also exists in $V f$, as no up to date information 234 is available. Conversely, there are at least five transcribed genes (LeB2, LeB3, LeB 4, LeB6, 235 LeB7) for legumin B subunits ${ }^{66,68}$, of which $L e B 3$ and $L e B 4$ have been mapped to 236 chromosome II and III, respectively ${ }^{66}$. The vicilin coding gene ${ }^{69}$ was also located on 237 chromosome II, near the centromere ${ }^{70-71}$. While the documented number of genes for $V f$ 238 globulins is relatively small, numerous legumin and vicilin minor subunits with various 239 molecular masses and isoelectric points can be observed in $2 \mathrm{D}$ gel electrophoresis analysis ${ }^{51}$, 240 suggesting that $V f$ globulins undergo extensive post-translational processing. A similar 241 occurrence has been found in other legumes including Medicago truncatula ${ }^{72}$ and Pisum 242 sativum $^{73}$.

243 There is considerable homology between $V f$ globulin subunits and those of other legumes 244 (Table S1), and where genome sequences are available, it is now possible to classify and 245 associate seed storage subunits to specific genome locations (Table S2). Considering the lack 246 of genome sequence for $V f$, this information is critical for synteny-based mapping of globulin 247 genes and QTLs. For instance, in M. truncatula, several genomic regions coding for globulins 248 have been mapped on chromosome I and VII ${ }^{72}$ which are notably syntenic with Vf 
Page $\mathbf{1 1}$ of $\mathbf{3 5}$

249 chromosome III and $\mathrm{V}^{39-40}$ where legumin $\mathrm{A}$ and B genes were previously located, 250 respectively ${ }^{66}$.

\section{Expression of globulin genes}

252 Seed protein content can be thought of as the final output of a number of biochemical and 253 physiological processes occurring throughout the crop life cycle, each of which are under the 254 control of a regulatory network. Abundance of globulin proteins is regulated by a network of

\section{Synthesis and accumulation of seed storage proteins}

268 Globulins are synthesized in the endoplasmic reticulum (ER) sorted in the Golgi body and transported to the protein storage vacuole (PSV) by vesicles ${ }^{72,}{ }^{76}$. During $V f$ seed

270 development, a diphasic pattern of protein accumulation exists in which proteins synthesized 271 during early developmental stages are only transitorily accumulated and subsequently 272 degraded to sustain the growing embryo while proteins accumulated after heart stage $(\sim 12$ 
Page 12 of $\mathbf{3 5}$

273 DAP) are mainly destined for storage into cotyledons' protein bodies ${ }^{77}$. During the latter

274 stage, globulin proteins show distinct expression patterns in which vicilin synthesis and 275 accumulation precedes that of legumin and $\alpha$ chain polypeptides of legumin appear earlier

276 than $\beta$ chains ${ }^{59}$. Similar pattern of vicilin and legumin gene expression has also been 277 reported in Medicago ${ }^{78}$ and soybean ${ }^{76}$.

278 The amount of protein accumulated during seed development can be attributed to various 279 genetic and environmental factors acting on various plant processes ranging from nutrient 280 uptake and transport, photosynthate production and remobilization to protein accumulation 281 rate in the storage organs. However, there are strong indications that mechanisms underlying 282 nitrogen $(\mathrm{N})$ uptake, transport and assimilation could explain the variation in protein content 283 more than any other factor. For instance, in pea, overexpression of the amino acid transporter 284 gene amino acid permease $(A A P)$, has been confirmed to play a critical role in increasing synthesis of seed storage proteins owing to increased leaf and pod phloem loading with free amino acids ${ }^{79}$. A similar mechanism could be attributed to the observed 2-3 times higher free amino acids in the cotyledons of high-protein (HP) $V f$ genotypes as compared to low-protein 288 genotypes ${ }^{80}$. In rice, a major seed protein content QTL harboring the OsAAP gene was 289 associated with higher uptake of amino acids and their distribution across plant tissues ${ }^{81}$. In 290 addition, QTL for N-fixation have been linked to QTL for total N accumulation in common 291 bean ${ }^{82}$ and pea ${ }^{83}$. Also, improved capacity for $\mathrm{N}$ uptake can be a candidate trait to relax the 292 yield-protein negative correlation. In fact, increased genetic capacity for $\mathrm{N}$ supply was 293 associated with increased seed size in $V f^{64}$ or seed number in pea ${ }^{79}$. These results should be 294 taken into consideration when screening for high protein content in $V f$. 
Page 13 of $\mathbf{3 5}$

295

296

297

298

299

300

301

302

303

304

\section{GENETIC IMPROVEMENT OF PROTEIN CONTENT AND QUALITY}

\section{Summary of the past work}

Several studies have focused on the genetic variation for protein content (Table 2) and to what extent protein content was correlated with yield of $V f$. One study indicated that protein content was variable between and within varieties $(n=33)$ with broad sense heritability of 0.70 and no significant correlation with seed weight ${ }^{31}$. However, when larger set of germplasm $(n=600)$ was screened, a clear negative relationship between seed weight and protein was detected although some large-seeded genotypes with above average protein content were also found ${ }^{65}$. Similarly, after four cycles of selection for protein content, Sjödin 32 concluded that protein content in $V f$ could be improved by selection but tended to negatively correlate with number of seeds per plant regardless of thousand seed weight. These early efforts also established the variability for S-AA content (Table 3) and nearly all investigations found a negative correlation between protein and S-AA content ${ }^{32,65,84}$. Under circumstances where desirable traits of interest are negatively correlated, deeper understanding of the genetic basis of the trade-offs between the traits and availability of appropriate tools to dissect and recombine them is crucial.

\section{Areas for future focus}

\section{Uncoupling the negative yield-protein correlation}

Correlation between traits can arise due to gene linkage or pleiotropy ${ }^{85}$,with the latter being most common in plants, and its resolution requires deeper understanding of both traits. Therefore, several possible mechanisms have been investigated in various crops in order to unlock protein-yield association. It is hypothesized that the negative correlation between the two traits result when the high demand for $\mathrm{N}$ during seed filling stage coincides with decline in soil nutrients in the rhizosphere and nitrogen fixation, resulting in re-mobilization of nitrogen from leaves, which in turn shortens grain filling and reduces seed weights ${ }^{86}$. This is 
Page 14 of $\mathbf{3 5}$

320 in line with findings by Egle, et al. ${ }^{87}$ who showed that majority of $\mathrm{N}$ accumulated during

321 seed filling in barley was remobilized from leaves and stems, but that ongoing $\mathrm{N}$ uptake

322 could also contribute. Furthermore, wheat genotypes with higher capability for post-anthesis

$323 \mathrm{~N}$ uptake deviate from grain-protein negative relationship ${ }^{88-89}$ and selection for this trait has

324 been therefore proposed as a possible criterion for simultaneous improvement of protein

325 content and grain yield. The genetic basis of post-flowering $\mathrm{N}$ uptake is not yet fully

326 understood either in cereals or in legumes but could be related to root structure and/or $\mathrm{N}$

327 transport capacity. For instance, pea genotypes with higher mineral nitrogen absorption and

328 symbiotic nitrogen fixation have shown enhanced seed $\mathrm{N}$ content and yield ${ }^{83}$. Moreover,

329 faster rate and relatively longer duration of $\mathrm{N}$ accumulation during seed development has

330 been reported as a possible mechanism for combining high protein and large seed size in

331 soybean ${ }^{90}$. The importance of $\mathrm{N}$ uptake capacity for protein content and yield was further

332 demonstrated by Peng, et al. ${ }^{81}$ who found major protein content QTL qPC1 harboring a 333 putative amino acid transporter gene (OSAAP6), which they proposed as candidate QTL for 334 simultaneous selection for yield and protein content in rice. These areas of enquiry are 335 amenable for further investigation and can potentially point to QTLs that can be used to 336 improve protein content in $V f$ without significant yield reduction.

Improving S-AA content by modifying legumin: vicilin ratio

338 Considering difficulties in genetic improvement of limiting amino acids through conventional 339 breeding approaches, several genetic engineering approaches have been attempted in various 340 crops over recent decades. Detailed information on these strategies and results obtained can 341 be found in Galili and Amir ${ }^{56}$. These included (i) overexpression of genes encoding proteins 342 rich in the limiting amino acid, (ii) in vitro modification of genes encoding proteins of 343 interest by adding more residues of the desired amino acid, (iii) introduction of genes coding 344 for protein rich in the limiting amino acid from one species to another target food crop, or by 
Page 15 of $\mathbf{3 5}$

345 (iv) modification of biosynthetic and catabolic pathways to directly increase accumulation of target amino acid or indirectly by increasing accumulation of proteins containing the limiting

347 amino acid. Yet, most of these attempts have not succeeded in producing new crop cultivars 348 combining increased protein quality with desired agronomic traits. In rare cases where reasonable success was achieved, commercialization of the improved cultivars was hindered by legal restrictions on GMO release ${ }^{56}$ and consumer resistance. Besides these challenges of consumer acceptability, the potential of transgenic approaches in $V f$ is limited by the inherently poor regenerating ability of $V f$ transgenics ${ }^{91}$.

Alternative strategies include direct selection on QTL for S-AA content or indirectly by selecting for greater relative expression of protein subunits rich in S-AA rich subunits. To our knowledge, soybean is the only legume crop in which QTLs for individual S-AA has been mapped ${ }^{92-93}$. Though total seed content of the S-AA per se would be a good indicator, it may not be sufficient when considering as selection criteria, due to uncertainty about what percentage of the total S-AA detected is indeed imbedded in the main storage proteins. In $V f$ and other legumes, since it is observed that the legumin protein subunit have relatively higher S-AA content compared to vicilin ${ }^{42,44,57-58}$, increasing legumin subunit in favor of vicilin would be expected to enhance the protein quality. In fact, the concept of manipulating legumin: vicilin (L/V) ratio to improve nutritional quality is not new in $V f$. It was previously reported that variation in $\mathrm{L} / \mathrm{V}$ ratio among varieties was consistent across years ${ }^{94}$ and environments 95 and concluded that $\mathrm{L} / \mathrm{V}$ ratio has genetic basis and could be used as a selection criteria to improve nutritional quality in $V f^{94-95}$. To our knowledge, since $\mathrm{L} / \mathrm{V}$ ratio based approach was suggested as a practical breeding strategy for improving nutritional 367 quality in soybean ${ }^{57}$, only study has tried to map QTLs for L/V ratio and showed colocation 368 between some QTLs for structural legumin and vicilin loci and $\mathrm{L} / \mathrm{V}$ ratio ${ }^{96}$. The recent 369 advances in $V f$ genetics tools such as development of $50 \mathrm{~K} \mathrm{SNP}$ array and high-density 
Page 16 of $\mathbf{3 5}$

370 linkage map may offer an unprecedented opportunity to discover novel QTLs that could represent targets for improving nutritional quality.

372

373

374

375

\section{Exploiting mutagenesis approaches}

Large-scale mutagenesis using physical or chemical mutagenic agents is a well-established method of inducing novel variation to meet human requirements, but which is unlikely to be present in nature. This approach is all the more justified in the case of $V f$ where the primary gene pool lacks any known wild relatives. Indeed, several mutagenesis efforts have produced new sets of morphological phenotypes in $V f^{40,97-98}$. However, no data is available on potential beneficial mutations in the seed composition of $V f$. Although Sjödin ${ }^{97}$ has reported to have identified some high protein content genotypes from a lot of seeds which had been mutagenized he could not ascertain whether the selected plants were genuine mutants or randomly isolated extremes in the original seed lot. There are several potential ways of exploiting induced mutations for improving protein content and/or quality. First, desirable mutations involving photosynthetic and $\mathrm{N}$ provision mechanisms can improve protein content. From ethyl methane sulfonate (EMS) mutagenized seeds, Duc ${ }^{98}$ discovered a supernodulating line with 3-4 times higher number of nodules compared to the parental line. Considering the close relationship between $\mathrm{N}$ fixation and protein content, such a trait could be exploited in breeding programs. Secondly, knockdown/knockout or regulatory mutations leading to absence of major protein subunits such as vicilins can result in improved nutritional quality by increasing the ratio of S-AA rich subunits like legumin and albumins. Such mutations could be cis-linked to the structural loci themselves or trans-acting factors that would need to be mapped de novo. For instance, mutants of PSABI5, a major trans-acting regulator of vicilin abundance in pea, have shown an increased legumin abundance ${ }^{72}$. Thirdly, presence or absence of certain subunits can enable dissection of genetic control of individual protein subunits via a QTL mapping approach ${ }^{55}$. Lastly, it is possible via a reverse 
Page $\mathbf{1 7}$ of $\mathbf{3 5}$

395

genetic screen to select non-synonymous mutations that convert non-S-AA residues to S-AA residues in S-AA poor storage proteins such as vicilins, although, only a proportion of codons are available for single base changes that would result in this outcome. Moreover, the physico-chemical properties of cysteine (disulfide bridge-forming) and methionine (hydrophobic) may cause steric constraints ${ }^{99}$. However even a single well-placed additional methionine in each vicilin could give rise to a significant step up in S-AA levels and this approach is therefore worth trying. On a more practical level, full exploitation of mutagenesis for the above purposes requires high-throughput and cheap phenotyping methods to screen tens of thousands of plants for nutritional and agronomic traits.

In summary, $V f$ is one of the most important legumes crops with great potential to fulfil multiple nutritional and ecological services for the current and future generations. However, $V f$ can only play this role if it meets certain producer and end-user expectations which requires plant breeders and research community to address both agronomic and nutritional constraints simultaneously. In drawing together a synthesis of the literature on $V f$ seed protein content, contribution of different storage protein classes to overall abundance and to varying relative amounts of essential amino acids, globulin structure and globulin-encoding genes, we aim to provide an updated and comprehensive primer for researchers interested in the nutritional optimization of faba beans. We discuss a range of approaches by which protein content could be increased (without compromising yield) and protein quality ameliorated, some of which have successful precedent in related legume species. These include: high resolution mapping of protein, $\mathrm{L}: \mathrm{V}$ ration and S-AA QTL using powerful modern quantitative genetics methods and genomics technologies; manipulation of known or still-tobe-discovered structural and regulatory genes by transformation and screening of mutant libraries to reveal novel structural and regulatory variants not found in nature. In parallel, as genome sequencing become cheaper and more genomic resources for $V f$ are accumulated, all 
Page 18 of $\mathbf{3 5}$

420 the above should become ever more efficient, enhancing the prospects of increasing protein

421 content and quality in this strategic crop.

422

423

424

425

426

427

428

429

430

431

432

433

434

435

436

\section{7}

438

439

440

441

442

443

444

445

446

447

\section{ABBREVIATIONS USED}

Vf, Vicia faba; S-AA, sulfur containing amino acid; V-C, vicine and convicine; QTL, quantitative trait loci; SDS-PAGE, sodium dodecyl sulfate polyacrylamide gel electrophoresis; HPLC, High Performance Liquid Chromatography; kDa, Kilo Dalton; N, nitrogen; GMO, Genetically Modified Organisms; EMS, Ethyl Methane Sulfonate (EMS)

\section{ACKNOWLEDGEMENTS}

The authors thank Islamic Development Bank (IDB) for the financial support during preparation of this manuscript.

\section{SUPPORTING INFORMATION}

Supplementary data including Figure S1 and Tables S1-S3 are provided in MS Word document.

\section{CONFLICT OF INTEREST}

The authors declare no competing financial interest.

\section{REFERENCES}

(1) Henchion, M.; Hayes, M.; Mullen, A.; Fenelon, M.; Tiwari, B., Future Protein Supply and Demand: Strategies and Factors Influencing a Sustainable Equilibrium. Foods 2017, 6 (7), 53.

(2) Young, V. R.; Pellett, P. L., Plant proteins in relation to human protein and amino acid nutrition. The American Journal of Clinical Nutrition 1994, 59 (5), 1203S-1212S.

(3) Smýkal, P.; Coyne, C. J.; Ambrose, M. J.; Maxted, N.; Schaefer, H.; Blair, M. W.; Berger, J.; Greene, S. L.; Nelson, M. N.; Besharat, N.; Vymyslický, T.; Toker, C.; Saxena, R. K.; Roorkiwal, M.; Pandey, M. K.; Hu, J.; Li, Y. H.; Wang, L. X.; Guo, Y.; Qiu, L. J.; Redden, R. J.; Varshney, R. K., Legume Crops Phylogeny and Genetic Diversity for Science and Breeding. Crit. Rev. Plant Sci. 2015, 34 (1-3), 43-104. 
Page 19 of 35

448 (4) Foyer, C. H.; Lam, H. M.; Nguyen, H. T.; Siddique, K. H.; Varshney, R. K.; Colmer, 449 T. D.; Cowling, W.; Bramley, H.; Mori, T. A.; Hodgson, J. M.; Cooper, J. W.; Miller, A. J.; 450 Kunert, K.; Vorster, J.; Cullis, C.; Ozga, J. A.; Wahlqvist, M. L.; Liang, Y.; Shou, H.; Shi, 451 K.; Yu, J.; Fodor, N.; Kaiser, B. N.; Wong, F. L.; Valliyodan, B.; Considine, M. J., 452 Neglecting legumes has compromised human health and sustainable food production. Nat 453 Plants 2016, 2, 16112.

454 (5) Duc, G., Faba bean (Vicia faba L). Field Crops Res. 1997, 53, 99-109.

455 (6) Tanno, K.-i.; Willcox, G., The origins of cultivation of Cicer arietinum L. and Vicia 456 faba L.: early finds from Tell el-Kerkh, north-west Syria, late 10th millennium b.p. 457 Vegetation History and Archaeobotany 2006, 15 (3), 197-204.

458 (7) Cubero, J. I., On the evolution of Vicia faba L. Theor. Appl. Genet. 1974, 45 (2), 4745951.

460 (8) FAOstat United Nations Organization for Food and Agriculture. (accessed 20 May).

461 (9) Duc, G.; Aleksić, J. M.; Marget, P.; Mikic, A.; Paull, J.; Redden, R. J.; Sass, O.; 462 Stoddard, F. L.; Vandenberg, A.; Vishnyakova, M.; Torres, A. M., Faba Bean. In Grain 463 Legumes, Ron, A. M. D., Ed. Springer Science+Business Media: New York, 2015; Vol. 10, 464 pp 141-178.

465 (10) Makkar, H. P. S.; Becker, K.; Abel, H.; Pawelzik, E., Nutrient contents, rumen protein 466 degradability and antinutritional factors in some colour- and white-flowering cultivars of 467 Vicia faba beans. J. Sci. Food Agric. 1997, 75 (4), 511-520.

468 (11) Schumacher, H.; Paulsen, H. M.; Gau, A. E.; Link, W.; Jurgens, H. U.; Sass, O.; 469 Dieterich, R., Seed protein amino acid composition of important local grain legumes Lupinus 470 angustifolius L., Lupinus luteus L., Pisum sativum L. and Vicia faba L. Plant Breeding 2011, $471 \quad 130(2), 156-164$.

472 (12) Kaskinen, T.; Lähteenoja, S.; Sokero, M.; Suomela, I., Strategic Business Examples 473 from Finland: The Growth of the Smartup Industry. In Factor X: Challenges, Implementation 474 Strategies and Examples for a Sustainable Use of Natural Resources, Lehmann, H., Ed. 475 Springer International Publishing: Cham, 2018; pp 325-333.

476 (13) Coda, R.; Varis, J.; Verni, M.; Rizzello, C. G.; Katina, K., Improvement of the protein 477 quality of wheat bread through faba bean sourdough addition. LWT - Food Science and 478 Technology 2017, 82 (Supplement C), 296-302.

479 (14) Rizzello, C. G.; Verni, M.; Koivula, H.; Montemurro, M.; Seppa, L.; Kemell, M.; 480 Katina, K.; Coda, R.; Gobbetti, M., Influence of fermented faba bean flour on the nutritional, 481 technological and sensory quality of fortified pasta. Food Funct. 2017, 8 (2), 860-871.

482 (15) VTT Gluten-free faba bean for bread and pasta. (accessed 25 July).

483 (16) Cernay, C.; Pelzer, E.; Makowski, D., A global experimental dataset for assessing 484 grain legume production. Scientific Data 2016, 3, 160084.

485 (17) Baddeley, J.; Jones, S.; Topp, C.; Watson, C.; Helming, J.; Stoddard, F. Biological 486 nitrogen fixation (BNF) by legume crops in Europe. www.legumefutures.de (accessed 487 January 4).

488 (18) Jensen, E. S.; Peoples, M. B.; Hauggaard-Nielsen, H., Faba bean in cropping systems. 489 Field Crops Res. 2010, 115 (3), 203-216.

490 (19) Köpke, U.; Nemecek, T., Ecological services of faba bean. Field Crops Res. 2010, 115 (3), 217-233.

(20) Perez-Maldonado, R. A.; Mannion, P. F.; Farrell, D. J., Optimum inclusion of field peas, faba beans, chick peas and sweet lupins in poultry diets. I. Chemical composition and layer experiments. British Poultry Science 1999, 40 (5), 667-673.

(21) Koivunen, E.; Tuunainen, P.; Valkonen, E.; Rossow, L.; Valaja, J., Use of faba beans (Vicia faba L. ) in diets of laying hens. Agricultural And Food Science 2014 23, 165-172. 
Page $\mathbf{2 0}$ of $\mathbf{3 5}$

(22) Lessire, M.; Gallo, V.; Prato, M.; Akide-Ndunge, O.; Mandili, G.; Marget, P.; Arese, P.; Duc, G., Effects of faba beans with different concentrations of vicine and convicine on egg production, egg quality and red blood cells in laying hens. Animal 2016, 1-9.

(23) Kawashima, H.; Bazin, M. J.; Lynch, J. M., A modelling study of world protein supply and nitrogen fertilizer demand in the 21st century. Environ. Conserv. 2002, 24 (1), 5057.

(24) Speedy, A. W. In Overview of world feed protein needs and supply, FAO Animal Production and Health Proceedings (FAO), FAO: 2004.

(25) Chiari, N., Food Security. The Challenge of Nutrition in the New Century. Relations. Beyond Anthropocentrism 2017, 5 (2), 145-156.

(26) $\mathrm{WHO} / \mathrm{FAO} / \mathrm{UNU}$, Protein and amino acid requirements in human nutrition. WHO Tech. Rep. Ser. 2007, (935), 1-265, back cover.

(27) Balyan, H. S.; Gupta, P. K.; Kumar, S.; Dhariwal, R.; Jaiswal, V.; Tyagi, S.; Agarwal, P.; Gahlaut, V.; Kumari, S., Genetic improvement of grain protein content and other healthrelated constituents of wheat grain. Plant Breeding 2013, 132 (5), 446-457.

(28) de Visser, C. L. M.; Schreuder, R.; Stoddard, F., The EU's dependency on soya bean import for the animal feed industry and potential for EU produced alternatives. OCL 2014, 21 (4), D407.

(29) Statista Meat consumption and vegetarianism in Europe - Statistics and Facts. https://www.statista.com/topics/3345/meat-consumption-and-vegetarianism-in-europe/ (accessed December 25).

(30) de Boer, J.; Aiking, H., Prospects for pro-environmental protein consumption in Europe: Cultural, culinary, economic and psychological factors. Appetite 2018, 121, 29-40.

(31) Griffiths, D. W.; Lawes, D. A., Variation in the crude protein content of field beans (Vicia faba L.) in relation to the possible improvement of the protein content of the crop. Euphytica 1978, 27 (2), 487-495.

(32) Sjödin, J., Protein Quantity and Quality in Vicia Faba. In Faba Bean Improvement: Proceedings of the Faba Bean Conference held in Cairo, Egypt, March 7-11, 1981, Hawtin, G.; Webb, C., Eds. Springer Netherlands: Dordrecht, 1982; pp 319-331.

(33) Frauen, M.; Röbbelen, G.; Ebrneyer, E., Quantitative Measurement of Quality Determining Constituents in Seeds of Different Inbred Lines from A World Collection of Vicia Faba. In Vicia baba: Agronomy, Physiology and Breeding, Hebblethwaite, P. D.; Dawkins, T. C. K.; Heath, M. C.; Lockwood, G., Eds. Springer-Science+Business Media, B.V.: Brussels-Luxembourg, 1984; Vol. 10, pp 279-287.

(34) Crépon, K.; Marget, P.; Peyronnet, C.; Carrouée, B.; Arese, P.; Duc, G., Nutritional value of faba bean (Vicia faba L.) seeds for feed and food. Field Crops Res. 2010, 115 (3), 329-339.

(35) Yu, E.-M.; Zhang, H.-F.; Li, Z.-F.; Wang, G.-J.; Wu, H.-K.; Xie, J.; Yu, D.-G.; Xia, Y.; Zhang, K.; Gong, W.-B., Proteomic signature of muscle fibre hyperplasia in response to faba bean intake in grass carp. 2017, 7, 45950.

(36) Rizzello, C. G.; Losito, I.; Facchini, L.; Katina, K.; Palmisano, F.; Gobbetti, M.; Coda, R., Degradation of vicine, convicine and their aglycones during fermentation of faba bean flour. Sci Rep 2016, 6, 32452.

(37) Coda, R.; Melama, L.; Rizzello, C. G.; Curiel, J. A.; Sibakov, J.; Holopainen, U.; Pulkkinen, M.; Sozer, N., Effect of air classification and fermentation by Lactobacillus plantarum VTT E-133328 on faba bean (Vicia faba L.) flour nutritional properties. Int. J. Food Microbiol. 2015, 193, 34-42.

(38) Khazaei, H.; Purves, R. W.; Song, M.; Stonehouse, R.; Bett, K. E.; Stoddard, F. L.; Vandenberg, A., Development and validation of a robust, breeder-friendly molecular marker for the vc-locus in faba bean. Mol. Breed. 2017, 37 (11), 140. 
Page $\mathbf{2 1}$ of $\mathbf{3 5}$

547 (39) Webb, A.; Cottage, A.; Wood, T.; Khamassi, K.; Hobbs, D.; Gostkiewicz, K.; White, 548 M.; Khazaei, H.; Ali, M.; Street, D.; Duc, G.; Stoddard, F. L.; Maalouf, F.; Ogbonnaya, F. C.; 549 Link, W.; Thomas, J.; O'Sullivan, D. M., A SNP-based consensus genetic map for synteny550 based trait targeting in faba bean (Vicia faba L.). Plant Biotechnol. J. 2016, 14 (1), 177-85. Genet 2016, 7, 150.

(41) Patil, G.; Mian, R.; Vuong, T.; Pantalone, V.; Song, Q.; Chen, P.; Shannon, G. J.; Carter, T. C.; Nguyen, H. T., Molecular mapping and genomics of soybean seed protein: a review and perspective for the future. Theor. Appl. Genet. 2017, 130 (10), 1975-1991.

(42) Liu, Y.; Wu, X.; Hou, W.; Li, P.; Sha, W.; Tian, Y., Structure and function of seed storage proteins in faba bean (Vicia faba L.). 3 Biotech 2017, 7 (1), 74.

(43) Shewry, P. R.; Casey, R., Seed Proteins. In Seed Proteins, Shewry, P. R.; Casey, R., Eds. Springer Netherlands: Dordrecht, 1999; pp 1-10.

(44) Joshi, J.; Pandurangan, S.; Diapari, M.; Marsolais, F., Comparison of Gene Families: Seed Storage and Other Seed Proteins. In The Common Bean Genome, Pérez de la Vega, M.; Santalla, M.; Marsolais, F., Eds. Springer International Publishing: Cham, 2017; pp 201-217. (45) Müntz, K.; Horstmann, C.; Schlesier, B., Vicia globulins. In Seed Proteins, Shewry, P. R.; Casey, R., Eds. Springer Netherlands: Dordrecht, 1999; pp 259-284.

(46) Kesari, P.; Sharma, A.; Katiki, M.; Kumar, P.; R Gurjar, B.; Tomar, S.; K Sharma, A.; Kumar, P., Structural, Functional and Evolutionary Aspects of Seed Globulins. Protein and peptide letters 2017, 24 (3), 267-277.

(47) Meng, G. T.; Ma, C. Y., Thermal properties of Phaseolus angularis (red bean) globulin. Food Chem. 2001, 73 (4), 453-460.

(48) Kimura, A.; Fukuda, T.; Zhang, M.; Motoyama, S.; Maruyama, N.; Utsumi, S., Comparison of Physicochemical Properties of 7S and 11S Globulins from Pea, Fava Bean, Cowpea, and French Bean with Those of Soybean-French Bean 7S Globulin Exhibits Excellent Properties. J. Agric. Food Chem. 2008, 56 (21), 10273-10279.

(49) Heng, L.; van Koningsveld, G. A.; Gruppen, H.; van Boekel, M. A. J. S.; Vincken, J. P.; Roozen, J. P.; Voragen, A. G. J., Protein-flavour interactions in relation to development of novel protein foods. Trends Food Sci. Technol. 2004, 15 (3), 217-224.

(50) Baumlein, H.; Wobus, U.; Pustell, J.; Kafatos, F. C., The legumin gene family: structure of a B type gene of Vicia faba and a possible legumin gene specific regulatory element. Nucleic Acids Res. 1986, 14 (6), 2707-20.

(51) Tucci, M.; Capparelli, R.; Costa, A.; Rao, R., Molecular heterogeneity and genetics of Vicia faba seed storage proteins. Theor. Appl. Genet. 1991, 81 (1), 50-58.

(52) Le Signor, C.; Gallardo, K.; Prosperi, J. M.; Salon, C.; Quillien, L.; Thompson, R.; Duc, G., Genetic diversity for seed protein composition in Medicago truncatula. Plant Genetic Resources 2005, 3 (1), 59-71.

(53) O'Kane, F. E.; Happe, R. P.; Vereijken, J. M.; Gruppen, H.; van Boekel, M. A. J. S., Characterization of Pea Vicilin. 1. Denoting Convicilin as the $\alpha$-Subunit of the Pisum Vicilin Family. J. Agric. Food Chem. 2004, 52 (10), 3141-3148.

(54) Krishnan, H. B.; Natarajan, S. S.; Oehrle, N. W.; Garrett, W. M.; Darwish, O., Proteomic Analysis of Pigeonpea (Cajanus cajan) Seeds Reveals the Accumulation of Numerous Stress-Related Proteins. J. Agric. Food Chem. 2017, 65 (23), 4572-4581.

(55) Boehm, J. D.; Nguyen, V.; Tashiro, R. M.; Anderson, D.; Shi, C.; Wu, X.; Woodrow, L.; Yu, K.; Cui, Y.; Li, Z., Genetic mapping and validation of the loci controlling 7S $\alpha^{\prime}$ and $11 \mathrm{~S}$ A-type storage protein subunits in soybean [Glycine $\max$ (L.) Merr.]. Theor. Appl. Genet. 2017, 1-13.

(56) Galili, G.; Amir, R., Fortifying plants with the essential amino acids lysine and methionine to improve nutritional quality. Plant Biotechnol. J. 2013, 11 (2), 211-22. 
Page 22 of $\mathbf{3 5}$

597 (57) Kwanyuen, P.; Pantalone, V. R.; Burton, J. W.; Wilson, R. F., A new approach to 598 genetic alteration of soybean protein composition and quality. J. Am. Oil Chem. Soc. 1997, 74 599 (8), 983-987.

600 (58) Jackson, P.; Boulter, D.; Thurman, D. A., A comparison of some properties of vicilin 601 and legumin isolated from seeds of Pisum sativum, Vicia faba and Cicer arietinum. New 602 Phytol. 196968 25-33.

603 (59) De Pace, C.; Delre, V.; Mugnozza, G. T. S.; Maggini, E.; Cremonini, R.; Frediani, M.; 604 Cionini, P. G., Legumin of Vicia faba major: accumulation in developing cotyledons, 605 purification, mRNA characterization and chromosomal location of coding genes. Theor. 606 Appl. Genet. 1991, 83, 17-23.

607 (60) Abirached-Darmency, M.; Dessaint, F.; Benlicha, E.; Schneider, C., Biogenesis of 608 protein bodies during vicilin accumulation in Medicago truncatula immature seeds. $B M C$ 609 Research Notes 2012, 5, 409-409.

610 (61) Gallardo, K.; Le Signor, C.; Vandekerckhove, J.; Thompson, R. D.; Burstin, J., 611 Proteomics of Medicago truncatula seed development establishes the time frame of diverse 612 metabolic processes related to reserve accumulation. Plant Physiol. 2003, 133 (2), 664-82.

613 (62) Rubio, L. A.; Perez, A.; Ruiz, R.; Guzman, M. A.; Aranda-Olmedo, I.; Clemente, A., 614 Characterization of pea (Pisum sativum) seed protein fractions. J. Sci. Food Agric. 2014, 94 615 (2), 280-7.

616 (63) Krishnan, H. B.; Bennett, J. O.; Kim, W.-S.; Krishnan, A. H.; Mawhinney, T. P., 617 Nitrogen Lowers the Sulfur Amino Acid Content of Soybean (Glycine max [L.] Merr.) by 618 Regulating the Accumulation of Bowman-Birk Protease Inhibitor. J. Agric. Food Chem. 619 2005, 53 (16), 6347-6354.

620 (64) Rolletschek, H.; Hosein, F.; Miranda, M.; Heim, U.; Gotz, K. P.; Schlereth, A.; 621 Borisjuk, L.; Saalbach, I.; Wobus, U.; Weber, H., Ectopic expression of an amino acid 622 transporter (VfAAP1) in seeds of Vicia narbonensis and pea increases storage proteins. Plant 623 Physiol. 2005, 137 (4), 1236-49.

624 (65) Lafiandra, D.; Polignano, G. B.; Filippetti, A.; Porceddu, E., Genetic variability for 625 protein content and S-aminoacids in broad-beans (Vicia faba L.). Die Kulturpflanze 1981, 29 626 (1), 115-127.

627 (66) Fuchs, J.; Schubert, I., Localization of seed protein genes on metaphase chromosomes 628 of Vicia faba via fluorescencein situ hybridization. Chromosome Research 1995, 3 (2), 94629100.

630 (67) Rerie, W. G.; Whitecross, M.; Higgins, T. J. V., Developmental and environmental 631 regulation of pea legumin genes in transgenic tobacco. Molecular and General Genetics 632 MGG 1991, $225(1), 148-157$.

633 (68) Heim, U.; Schubert, R.; Baumlein, H.; Wobus, U., The legumin gene family: structure 634 and evolutionary implications of Vicia faba B-type genes and pseudogenes. Plant Mol. Biol. 635 1989, $13(6), 653-63$.

636 (69) Weschke, W.; Bassüner, R.; Van Hai, N.; Czihal, A.; Baümlein, H.; Wobus, U., The 637 structure of a Vicia faba vicilin gene. Biochemie und Physiologie der Pflanzen 1988, 183 (2638 3), 233-242.

639 (70) Jiri, M.; Winfriede, W.; Helmut, B.; Uta, P.; Andreas, H.; Ulrich, W.; Ingo, S., 640 Localization of vicilin genes via polymerase chain reaction on microisolated field bean 641 chromosomes. The Plant Journal 1993, 3 (6), 883-886.

642 (71) Fuchs, J.; Joos, S.; Licheter, P.; Schubert, I., Localization of Vicilin Genes on Field 643 Bean Chromosome II by Fluorescent in situ Hybridization. J. Hered. 1994, 85 (6), 487-488.

644 (72) Le Signor, C.; Aimé, D.; Bordat, A.; Belghazi, M.; Labas, V.; Gouzy, J.; Young, N. 645 D.; Prosperi, J.-M.; Leprince, O.; Thompson, R. D.; Buitink, J.; Burstin, J.; Gallardo, K., 
Page $\mathbf{2 3}$ of $\mathbf{3 5}$

646 Genome-wide association studies with proteomics data reveal genes important for synthesis, 647 transport and packaging of globulins in legume seeds. New Phytol. 2017, 214 (4), 1597-1613. 648 (73) Bourgeois, M.; Jacquin, F.; Savois, V.; Sommerer, N.; Labas, V.; Henry, C.; Burstin, 649 J., Dissecting the proteome of pea mature seeds reveals the phenotypic plasticity of seed 650 protein composition. Proteomics 2009, 9 (2), 254-71. Hongwei, J. Dawei, X. Zhengong Y · Rong, .' J . Chunyan, L. Wei, Y. Zhenbang. H. Xiaoxia, W.; Jun, L.; Qingshan, C., Meta $\square$ analysis and transcriptome profiling reveal hub genes for soybean seed storage composition during seed development. Plant, Cell Environ. 2018, $0(0), 1-19$.

(75) Verdier, J.; Thompson, R. D., Transcriptional regulation of storage protein synthesis during dicotyledon seed filling. Plant Cell Physiol. 2008, 49 (9), 1263-71.

(76) Mori, T.; Maruyama, N.; Nishizawa, K.; Higasa, T.; Yagasaki, K.; Ishimoto, M.; Utsumi, S., The composition of newly synthesized proteins in the endoplasmic reticulum determines the transport pathways of soybean seed storage proteins. The Plant Journal 2004, 40 (2), 238-249.

(77) Panitz, R.; Borisjuk, L.; Manteuffel, R.; Wobus, U., Transient expression of storageprotein genes during early embryogenesis ofVicia faba: synthesis and metabolization of vicilin and legumin in the embryo, suspensor and endosperm. Planta 1995, 196 (4), 765-774.

(78) Wang, X. D.; Song, Y.; Sheahan, M. B.; Garg, M. L.; Rose, R. J., From embryo sac to oil and protein bodies: embryo development in the model legume Medicago truncatula. New Phytol. 2012, 193 (2), 327-38.

(79) Zhang, L.; Garneau, M. G.; Majumdar, R.; Grant, J.; Tegeder, M., Improvement of pea biomass and seed productivity by simultaneous increase of phloem and embryo loading with amino acids. Plant $J$. 2015, 81 (1), 134-46.

(80) Golombek, S.; Rolletschek, H.; Wobus, U.; Weber, H., Control of storage protein accumulation during legume seed development. J. Plant Physiol. 2001, 158 (4), 457-464.

(81) Peng, B.; Kong, H.; Li, Y.; Wang, L.; Zhong, M.; Sun, L.; Gao, G.; Zhang, Q.; Luo, L.; Wang, G.; Xie, W.; Chen, J.; Yao, W.; Peng, Y.; Lei, L.; Lian, X.; Xiao, J.; Xu, C.; Li, X.; He, Y., OsAAP6 functions as an important regulator of grain protein content and nutritional quality in rice. Nature Communications 2014, 5, 4847.

(82) Ramaekers, L.; Galeano, C. H.; Garzón, N.; Vanderleyden, J.; Blair, M. W., Identifying quantitative trait loci for symbiotic nitrogen fixation capacity and related traits in common bean. Mol. Breed. 2013, 31 (1), 163-180.

(83) Bourion, V.; Rizvi, S. M. H.; Fournier, S.; Larambergue, H. d.; Galmiche, F.; Marget, P.; Duc, G.; Burstin, J., Genetic dissection of nitrogen nutrition in pea through a QTL approach of root, nodule, and shoot variability. Theor. Appl. Genet. 2010, 121, 71-86.

(84) Griffiths, D. W., An Assesment of the Potential for Improving the Nutritive Value of Field Beans (Vicia Faba)- A Progress Report. In Vicia faba: Agronomy, Physiology and Breeding, Hebblethwaite, P. D.; Dawkins, T. C. K.; Heath, M. C.; Lockwood, G., Eds. Springer-Science+Business Media, B.V. : Brussels-Luxembourg, 1984; Vol. 10, pp 271-278.

(85) Chen, Y.; Lübberstedt, T., Molecular basis of trait correlations. Trends Plant Sci. 2010, $15(8), 454-461$.

(86) Munier-Jolain, N.; Larmure, A.; Salon, C., Determinism of carbon and nitrogen reserve accumulation in legume seeds. C. R. Biol. 2008, 331 (10), 780-787.

(87) Egle, K.; Beschow, H.; Merbach, W., Nitrogen allocation in barley: Relationships between amino acid transport and storage protein synthesis during grain filling. Canadian Journal of Plant Science 2015, 95 (3), 451-459.

(88) Bogard, M.; Allard, V.; Brancourt-Hulmel, M.; Heumez, E.; Machet, J.-M.; Jeuffroy, M.-H.; Gate, P.; Martre, P.; Le Gouis, J., Deviation from the grain protein concentration- 
Page $\mathbf{2 4}$ of $\mathbf{3 5}$

696 grain yield negative relationship is highly correlated to post-anthesis $\mathrm{N}$ uptake in winter 697 wheat. J. Exp. Bot. 2010, 61 (15), 4303-4312.

698 (89) Taulemesse, F.; Le Gouis, J.; Gouache, D.; Gibon, Y.; Allard, V., Bread Wheat 699 (Triticum aestivum L.) Grain Protein Concentration Is Related to Early Post-Flowering 700 Nitrate Uptake under Putative Control of Plant Satiety Level. PLoS ONE 2016, 11 (2), $701 \mathrm{e} 0149668$.

702 (90) Poeta, F.; Ochogavia, A. C.; Permingeat, H. R.; Rotundo, J. L., Storage-Associated 703 Genes and Reserves Accumulation in Soybean Cultivars Differing in Physiological Strategies 704 for Attaining High Seed Protein Concentration. Crop Sci. 2017, 57 (1), 427-436.

705 (91) Hanafy, M.; Pickardt, T.; Kiesecker, H.; Jacobsen, H.-J., Agrobacterium-mediated 706 transformation of faba bean (Vicia faba L.) using embryo axes. Euphytica 2005, 142 (3), 227 707236.

708 (92) Wang, X.; Jiang, G.-L.; Song, Q.; Cregan, P. B.; Scott, R. A.; Zhang, J.; Yen, Y.; 709 Brown, M., Quantitative trait locus analysis of seed sulfur-containing amino acids in two 710 recombinant inbred line populations of soybean. Euphytica 2014, 201 (2), 293-305.

711 (93) Warrington, C. V.; Abdel-Haleem, H.; Hyten, D. L.; Cregan, P. B.; Orf, J. H.; Killam, 712 A. S.; Bajjalieh, N.; Li, Z.; Boerma, H. R., QTL for seed protein and amino acids in the 713 Benning x Danbaekkong soybean population. Theor. Appl. Genet. 2015, 128 (5), 839-50.

714 (94) Martensson, P., Variation in legumin : vicilin ratio between and within cultivars of 715 Vicia faba L. var. minor. Martinus Nijhoff. World crops: production, utilization and 716 description, volume 3.: The Hague, 1980; pp 159-172.

717 (95) Gatehouse, J.; Croy, R.; McIntosh, R.; Paul, C.; Boulter, D., Quantitative and 718 qualitative variation in the storage proteins of material from the EEC joint field bean test. 719 Quantitative and qualitative variation in the storage proteins of material from the EEC joint 720 field bean test. 1980, 173-188.

721 (96) Ma, Y.; Kan, G.; Zhang, X.; Wang, Y.; Zhang, W.; Du, H.; Yu, D., Quantitative Trait 722 Loci (QTL) Mapping for Glycinin and beta-Conglycinin Contents in Soybean (Glycine max 723 L. Merr.). J. Agric. Food Chem. 2016, 64 (17), 3473-83.

724 (97) Sjödin, J., Induced morphological variation in Vicia faba L. Hereditas 1971, 67 (2), 155-179.

(98) Duc, G., Mutagenesis of faba bean (Vicia faba L.) and the identification of five different genes controlling no nodulation, ineffective nodulation or supernodulation. Euphytica 1995, 83 (2), 147-152.

(99) Brosnan, J. T.; Brosnan, M. E., The sulfur-containing amino acids: an overview. $J$. Nutr. 2006, 136 (6 Suppl), 1636s-1640s.

(100) Utsumi, S.; Yokoyama, Z.-i.; Mori, T., Comparative Studies of Subunit Compositions of Legumins from Various Cultivars of Vicia faba L. Seeds. Agric. Biol. Chem. 1980, 44 (3), 595-601.

(101) Fontes, E. P. B.; Moreira, M. A.; Davies, C. S.; Nielsen, N. C., Urea-elicited changes in relative electrophoretic mobility of certain glycinin and $\beta$-conglycinin subunits. Plant Physiol. 1984, 76 (3), 840-842.

(102) Poysa, V.; Woodrow, L.; Yu, K., Effect of soy protein subunit composition on tofu quality. Food Res. Int. 2006, 39 (3), 309-317.

(103) Mertens, C.; Dehon, L.; Bourgeois, A.; Verhaeghe-Cartrysse, C.; Blecker, C., Agronomical factors influencing the legumin/vicilin ratio in pea (Pisum sativum L.) seeds. $J$. Sci. Food Agric. 2012, 92 (8), 1591-6.

(104) Ladjal E, Y.; Boudries, H.; Mohamed, C.; Romero, A., Pea, Chickpea and Lentil Protein Isolates: Physicochemical Characterization and Emulsifying Properties. 2015; Vol. 744 11, p 43-51. 
Page $\mathbf{2 5}$ of $\mathbf{3 5}$

745

746

747

748

749

750

751

752

753

754

755

756

757

758

759

760

761

762

763

764

765

766

767

768

769

770

771

772

773

774

775

776

777

778

779

780

781

1

(105) Schumacher, H.; Paulsen, H. M.; Gau, A. E., Phenotypical indicators for the selection of methionine enriched local legumes in plant breeding. Agriculture and Forestry Research 2009 4(59), 339-344.

(1)

0

2

3

54

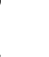

7

8

9

62

63

4

\section{FIGURE CAPTIONS}

Figure 1. Global distribution of $V f$ cultivation (A) and the major producing countries (B). Data was sourced from FAOstats and distribution map was generated using Tableau Public 2018.1.

Figure 2. Predicted ribbon structures of $V f$ globulins. Vicilin (A) is trimeric consisting of 3 protomers ( $a=$ light blue, $b=$ magenta and $c=$ green) while legumin is hexameric consisting of legumin A (B) and legumin B (C). Spherical balls in legumin subunits represent disulfide bonds. The models were generated using SWISS-MODEL and processed with PyMOL software. Model description details are in Table S3.

Figure 3. 1D SDS-PAGE showing the major subunits of $V f$ globulins and the variation in protein band abundance among 11 inbred lines.

Figure 4. Amino acid composition (g/16 g N) of $V f$ seed protein (Makkar et al., 1997; Grela et al., 2017). It clearly shows the abundance of several amino acids and deficiency of the S-AA in $V f$ proteins.

Figure 5. Relative abundances of limiting amino acids within legumin and vicilin coding sequences of 7 legume species (Table S1). Annotated protein accessions were obtained from Uniprot and the amino acid residues were counted using "seqinr" package in R. 
Page 26 of $\mathbf{3 5}$

782

783

784

785

786

787

788

789

790

791

792

793

794

795

796

797

798

799

800

Table 1. Major globulin polypeptides of $V f$ and related species as annotated on SDS-PAGE

\begin{tabular}{|c|c|c|c|c|c|}
\hline \multirow[t]{2}{*}{ Species } & \multicolumn{2}{|c|}{ 11S legumin-like ( kDa) } & \multicolumn{2}{|c|}{ 7S Vicilin-like ( kDa) } & \multirow[t]{2}{*}{ Ref. } \\
\hline & $\alpha$ chain & $\beta$ chain & vicilin & Convicilin & \\
\hline \multirow{6}{*}{ Vicia faba } & 38 & $22-24$ & $31-65$ & & De Pace, et al. ${ }^{59}$ \\
\hline & $38-47$ & .. & .. & 64 & Liu, et al. ${ }^{42}$ \\
\hline & 40 & 20 & .. & .. & Gatehouse, et al. ${ }^{95}$ \\
\hline & $35-39$ & $23-25$ & $42-48$ & 66 & Tucci, et al. ${ }^{51}$ \\
\hline & $36-51$ & $19-23$ & .. & .. & Utsumi, et al. ${ }^{100}$ \\
\hline & 40 & $23-24$ & 54 & $\sim 73$ & This study \\
\hline \multirow{3}{*}{ Medicago truncatulla } & $36-46$ & $23-24$ & $46-47$ & $60-92$ & Le Signor, et al. ${ }^{52}$ \\
\hline & $42-46$ & 23 & $46-47$ & & Gallardo, et al. ${ }^{61}$ \\
\hline & $38-41$ & .. & 47 & 70 & Le Signor, et al. ${ }^{72}$ \\
\hline \multirow{4}{*}{ Glycine $\max *$} & 37 & 20 & $52-72$ & & Fontes, et al. ${ }^{101}$ \\
\hline & 37 & 20 & $52-72$ & & Boehm, et al. ${ }^{55}$ \\
\hline & 37 & 20 & $52-72$ & & Poysa, et al. ${ }^{102}$ \\
\hline & $37-44$ & $17-22$ & $53-76$ & & Krishnan, et al. ${ }^{54}$ \\
\hline
\end{tabular}


Page $\mathbf{2 7}$ of $\mathbf{3 5}$

\begin{tabular}{llllll} 
& $40-45$ & $18-25$ & 53 & $60-88$ & Bourgeois, et al. $^{73}$ \\
Pisum sativum & 40 & 24.8 & 47.2 & 67.2 & Mertens, et al. $^{103}$ \\
& 40 &. &. & $>70$ & Rubio, et al. ${ }^{62}$ \\
& 37 & 25 & $43-53$ & 70 & Ladjal E, et al. $^{104}$ \\
\hline
\end{tabular}

*7S subunits of G.max consist of $\alpha$, $\alpha$ and $\beta$ polypeptides.

801

802

803

804

805

806

807

808

809

810

811

812

813

814

815

816

Table 2. Genetic variability in seed protein content in $V f$

\begin{tabular}{lll}
\hline No. genotypes & Protein content $\mathbf{( \% )}$ & Reference \\
\hline 33 & $22-38$ & Griffiths and Lawes ${ }^{31}$ \\
600 & $19-34$ & Lafiandra, et al. $^{65}$ \\
125 & $22-36$ & Sjödin \\
& \\
125 & $29-38$ & Frauen, et al. $^{33}$ \\
30 & $23-39$ & Griffiths $^{84}$ \\
12 & $26-30$ & Makkar, et al. $^{10}$ \\
\hline
\end{tabular}

817

818

819

820 
Page $\mathbf{2 8}$ of $\mathbf{3 5}$

821

822

823

824

825

826

827

828

829

830

831

832

833

834

835

836

837

838

Table 3. Genetic variability in sulfur-containing amino acids in $V f(\mathrm{~g} / 16 \mathrm{~g} \mathrm{~N})$

\begin{tabular}{llll}
\hline No. genotypes & Methionine & Cysteine & Reference \\
\hline 111 & $0.6-1.0$ & $1.0-1.5$ & Lafiandra, et al. ${ }^{6{ }^{*}}$ \\
125 & $0.8-1.4$ & $1.3-1.4$ & Sjödin $^{32^{*}}$ \\
125 & $0.1-0.2$ & $0.2-0.6$ & Frauen, et al. $^{33}$ \\
12 & $0.8-1.1$ & $1.1-1.4$ & Makkar, et al. $^{10}$ \\
50 & $0.6-0.9$ & $1.0-1.4$ & Schumacher, et al. $^{105}$ \\
46 & $0.6-0.9$ & $0.9-1.2$ & Schumacher, et al. \\
\end{tabular}

* S-AA reported as \% protein 
Page $\mathbf{2 9}$ of $\mathbf{3 5}$

842

843

844

845

846

847

848

849

850

851

852

853

854

855

856

857

858

859

860

$861 \quad$ Figure 1

A

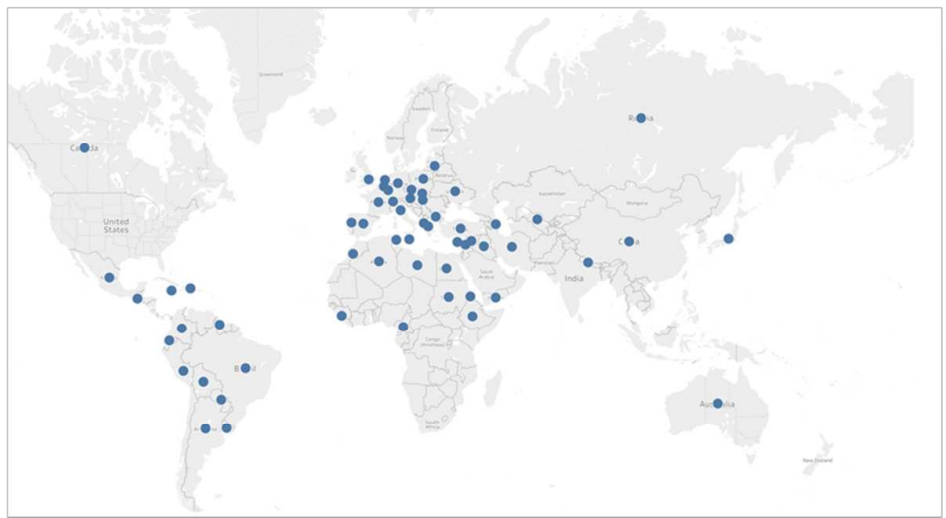

B

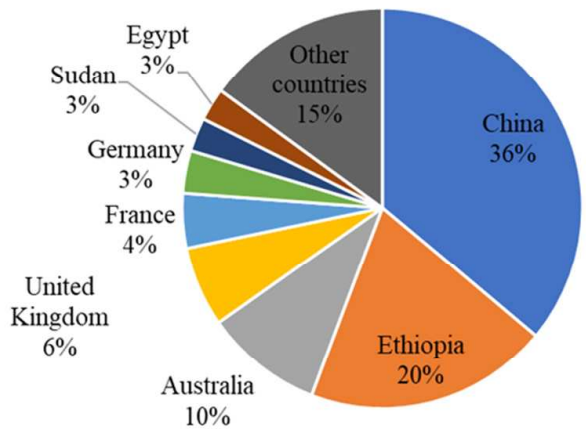

862

863 
Page $\mathbf{3 0}$ of $\mathbf{3 5}$

865

866

867

868

869

870

871

872

873

874

875

876

877

878

879

880

881

882

883

$884 \quad$ Figure 2

885

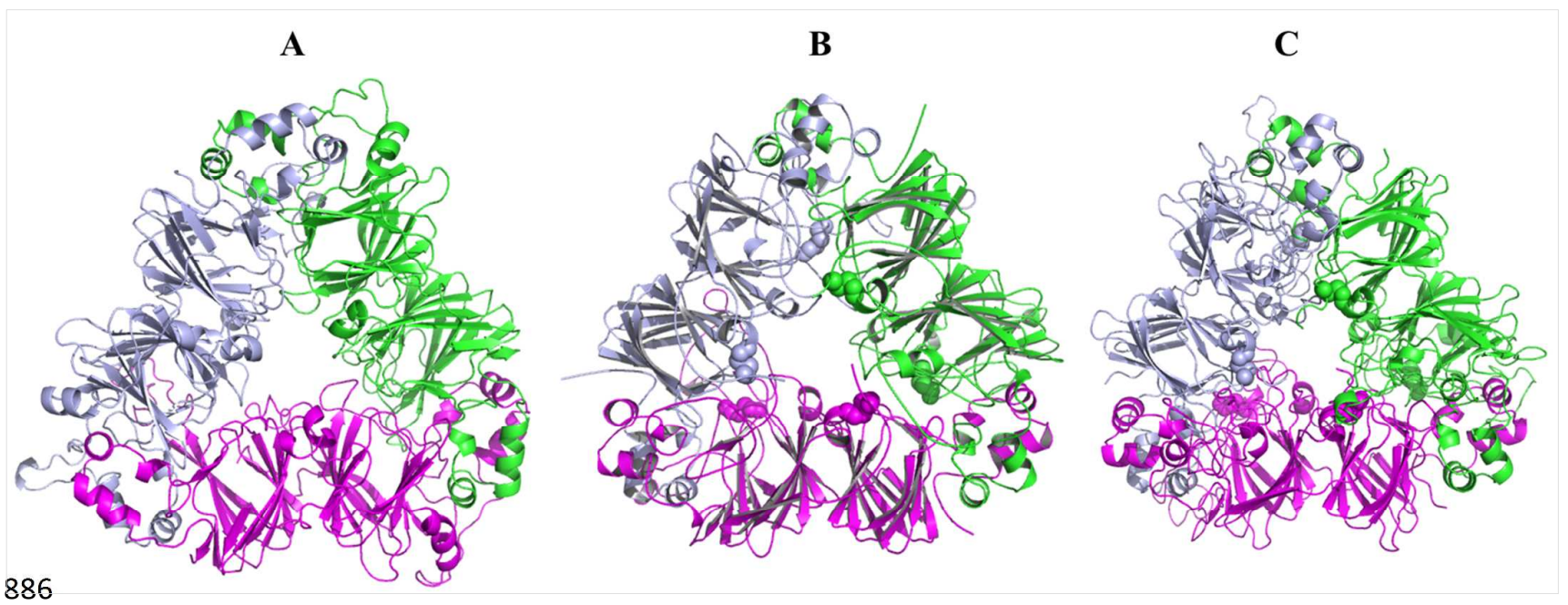


Page $\mathbf{3 1}$ of $\mathbf{3 5}$

887

888

889

890

891

892

893

894

895

896

897

898

899

900

901

902

903

904

905

906 Figure 3

907

908 
Page $\mathbf{3 2}$ of $\mathbf{3 5}$

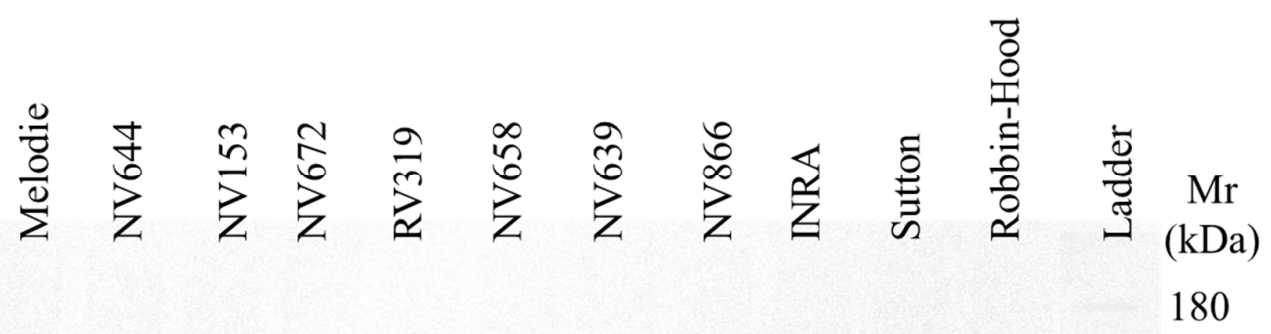

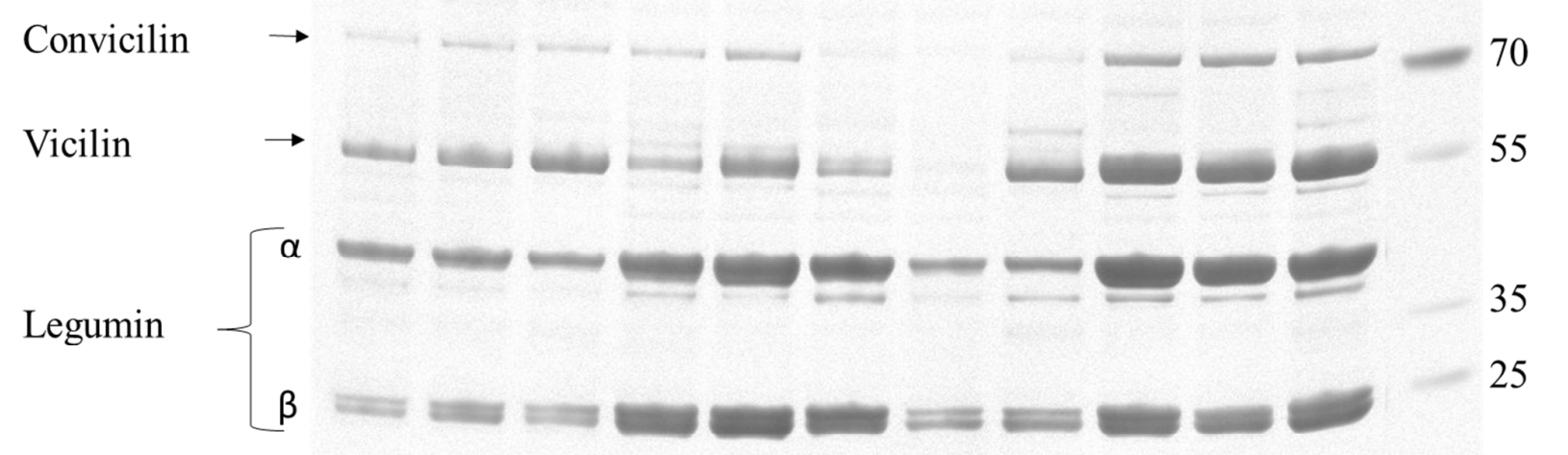

909

910

911

912

913

914

915

916

917

918

919

920

$921 \quad$ Figure 4 
Page $\mathbf{3 3}$ of $\mathbf{3 5}$

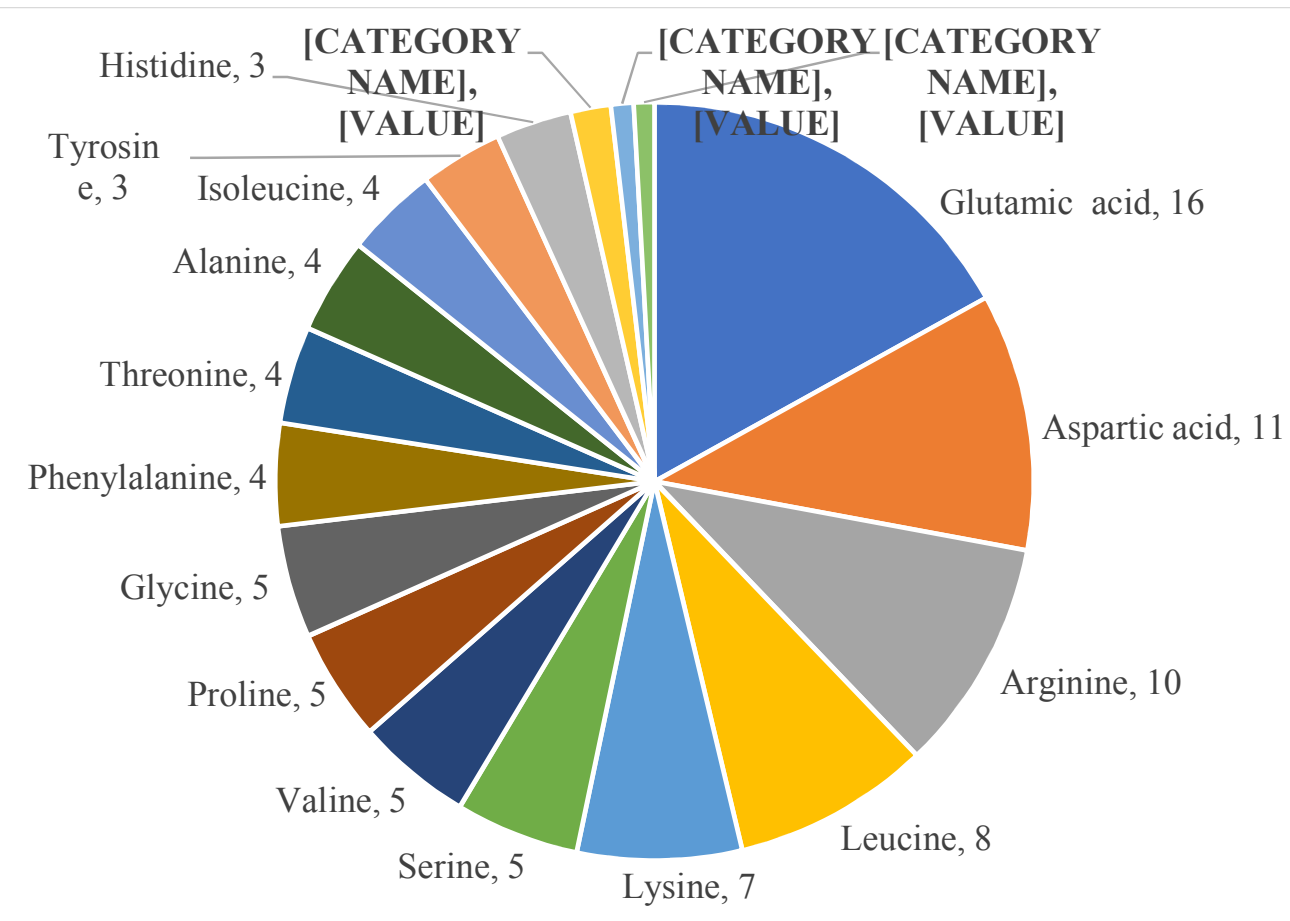

922

923

924

925

926

927

928

929

930

931

932

933

934

935

936

937

938

939 Figure 5 
Page $\mathbf{3 4}$ of $\mathbf{3 5}$

940

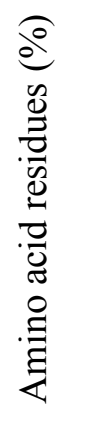

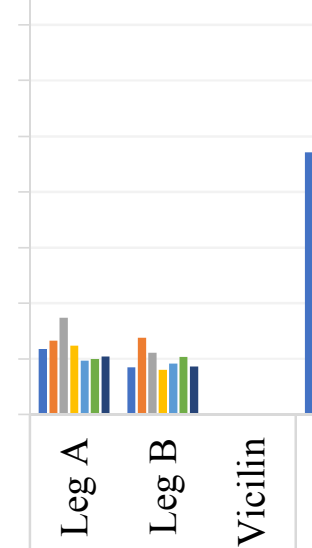

Cystine

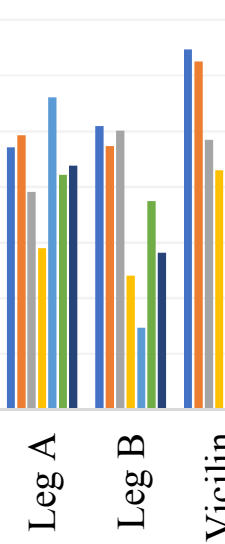

Lysine

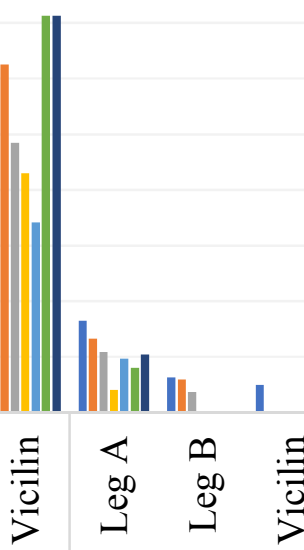

Methionine
- Cajanus cajan

- Cicer arietinum

- Glycine max

- Lupinus angustifolius

- Medicago truncatula

- Pisum sativum

- Vicia faba

941

942

943

944

945

946

947

948

949

950

951

952

953

954

955

956

957

958

959

960

961

\section{TOC Graphic}


Page $\mathbf{3 5}$ of $\mathbf{3 5}$

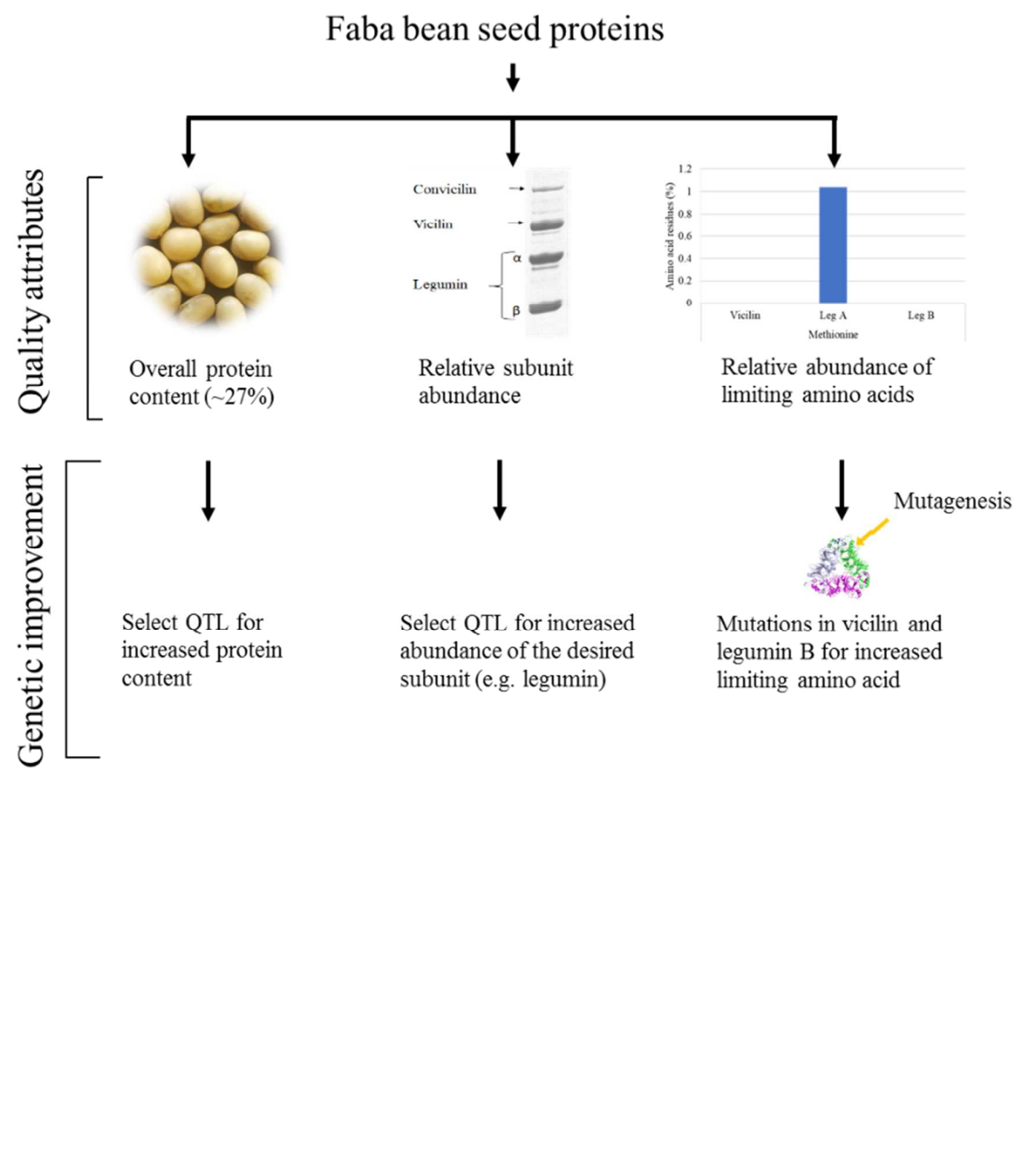

